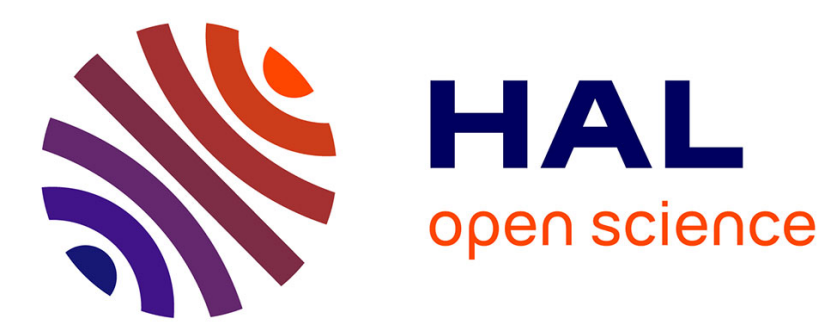

\title{
Substrate and interface effects in GaAs fet's
}

Henri Tranduc, P. Rossel, Jacques Graffeuil, C. Azizi, G. Nuzillat, G. Bert

\section{To cite this version:}

Henri Tranduc, P. Rossel, Jacques Graffeuil, C. Azizi, G. Nuzillat, et al.. Substrate and interface effects in GaAs fet's. Revue de Physique Appliquée, 1978, 13 (12), pp.655-659. 10.1051/rphysap:019780013012065500 . jpa-00244521

\section{HAL Id: jpa-00244521 \\ https://hal.science/jpa-00244521}

Submitted on 1 Jan 1978

HAL is a multi-disciplinary open access archive for the deposit and dissemination of scientific research documents, whether they are published or not. The documents may come from teaching and research institutions in France or abroad, or from public or private research centers.
L'archive ouverte pluridisciplinaire HAL, est destinée au dépôt et à la diffusion de documents scientifiques de niveau recherche, publiés ou non, émanant des établissements d'enseignement et de recherche français ou étrangers, des laboratoires publics ou privés. 


\title{
SUBSTRATE AND INTERFACE EFFECTS IN GaAs FET'S ( $\left.{ }^{\mathbf{1}}\right)$
}

\author{
H. TRANDUC $\left({ }^{*}\right)$, P. ROSSEL $\left({ }^{*}\right)$, J. GRAFFEUIL $\left({ }^{* *}\right)$, C. AZIZI $\left({ }^{*}\right)$, G. NUZILLAT $\left({ }^{+}\right)$ \\ and G. BERT $\left(^{+}\right)$
}

$\left({ }^{*}\right)$ Laboratoire d'Automatique et d'Analyse des Systèmes du CNRS $\left({ }^{2}\right)$,

7, avenue du Colonel-Roche, 31400 Toulouse, France

$\left({ }^{* *}\right)$ Université Paul-Sabatier $\left({ }^{2}\right), 118$, route de Narbonne, 31077 Toulouse, France

$\left(^{+}\right)$Laboratoire Central de Recherches Thomson CSF, Domaine de Corbeville, 91401 Orsay, France

\begin{abstract}
Résumé. - Dans cette communication on décrit l'effet de la polarisation du substrat sur les caractéristiques électriques du transistor à effet de champ à l'arseniure de gallium, réalisé à partir d'une couche $\mathbf{N}$ épitaxiée sur substrat semi-isolant compensé au chrome. Une analyse basée sur l'existence d'une double charge d'espace à l'interface semiconducteur-semi-isolant, est proposée et appliquée à la détermination des paramètres de la couche active et des paramètres de l'interface. Les.propriétés des caractéristiques de courant de drain aux basses températures et celles de l'admittance de sortie en basses fréquences, sont attribuées à la réponse dynamique de cette double charge d'espace.
\end{abstract}

\begin{abstract}
In this paper, the experimental results describing the substrate bias effect on the Schottky gate capacitance-voltage and the DC current-voltage characteristics of GaAs FET's (N-type epilayer on semi-insulating Cr-doped substrate) are reported. These results are accounted for by the formation of a double space-charge in the N-layer and in the S.I. substrate in the vicinity of the interface. A theoretical analysis is proposed and appropriate methods for obtaining both the $\mathbf{N}$ active layer and the interface parameters (fixed interface charge value, deep centers density in the S.I. GaAs) are shown. The deep level charge effect on the low temperature drain current-drain voltage characteristics, is described.
\end{abstract}

Introduction. - In gallium arsenide Schottky barrier field-effect transistors, made from $\mathrm{N}$-type epilayer on semi-insulating substrate, it is found that the interface characteristics strongly influence the electrical properties : low-frequency drain current relaxation phenomenon, R.F. and noise performances [1]. In this paper, the experimental results describing the substrate bias effect on the Schottky gate capacitance-voltage and the DC current-voltage characteristics will be reported. It will be shown that a space-charge appears in the $\mathrm{N}$-layer in the interface vicinity. Its properties depend on the interface parameters, i.e. fixed interface charge, deep centers charge in the S.I. A theoretical analysis of the drain current variations will be proposed and applied to the $\mathbf{N}$ active layer (thickness, effective doping concentration, carrier mobility) and interface (fixed interface charge value, deep centers concentration in the S.I.) parameters determination.

1. Experimental results. - The studied structures are made from an N-type Ge-doped GaAs layer of thickness $d$ between 0.2 and $0.5 \mu \mathrm{m}$. This epilayer

( $\left.{ }^{1}\right)$ Preliminary results concerning this communication have been previously accepted for publication (in French) in the Revue de Physique Appliquée.

$\left.{ }^{2}\right)$ G.R.E.C.O., Microondes, C.N.R.S. no 11. is obtained by a low pressure organo-metallic compounds cracking [2] directly on Cr-doped semiinsulating substrate of thickness $D$ equal to $400 \mu \mathrm{m}$. The Schottky gate $(L=1 \mu \mathrm{m}$ or $50 \mu \mathrm{m}, Z=300 \mu \mathrm{m}$ is made from an Au-Pt-Ti metallization. The lateral $\mathrm{Au}-\mathrm{Ge}$ alloyed ohmic contacts are the source and the drain electrodes and, the ohmic contact (Au-Ge) on the S.I. bottom is called the substrate electrode (Fig. 1).

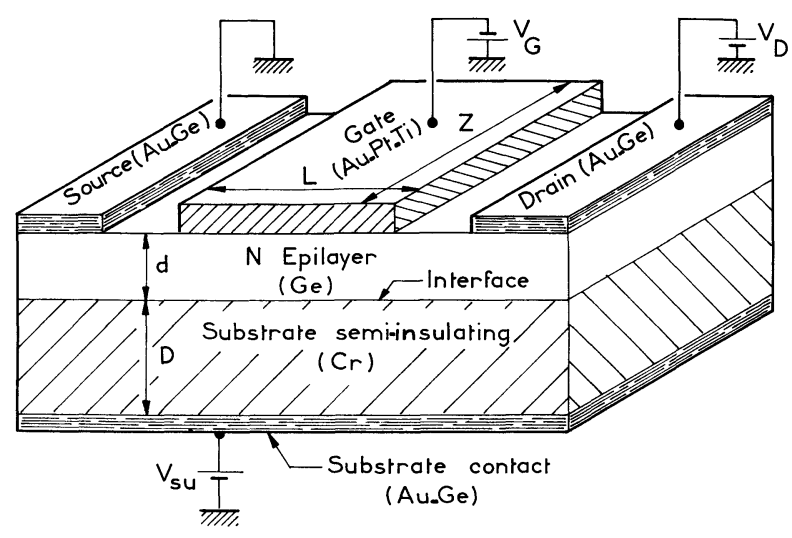

FIG. 1. - Configuration of the device. Definition of the bias voltages. 
1.1 Capacitance-voltage CHaRacteristics. At given substrate bias $V_{\text {su }}$, the characteristic (Fig. 2) is clearly defined in three parts : (i) a slow variation for $0<V_{\mathrm{G}}<V_{\mathrm{TC}}$, (ii) an abrupt decrease between $V_{\mathrm{TC}}$ and $V_{\mathrm{C}}$, (iii) a third region where the capacitance tends towards the null value. The characteristic translates with a change of $V_{\mathrm{su}}$. Thus, the variations of the quantity $-\frac{C^{* 3}}{q \varepsilon_{0} \varepsilon_{s}}\left(\frac{\partial C^{*}}{\partial V_{\mathrm{G}}}\right)^{-1}$ as a function of $\frac{\varepsilon_{0} \varepsilon_{\mathrm{s}}}{C^{*}}$, usually identified to the donor distribution, where $C^{*}$ is the capacitance by area unit, will also translate and strongly depend on the substrate bias.

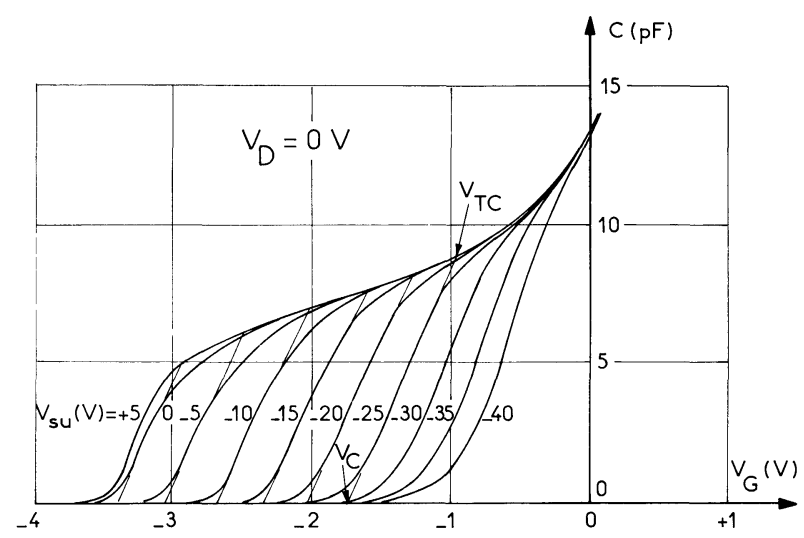

FIG. 2. - Experimental variations of the Schottky gate- (source drain) capacitance as a function of the gate voltage. Substrate voltage as parameter.

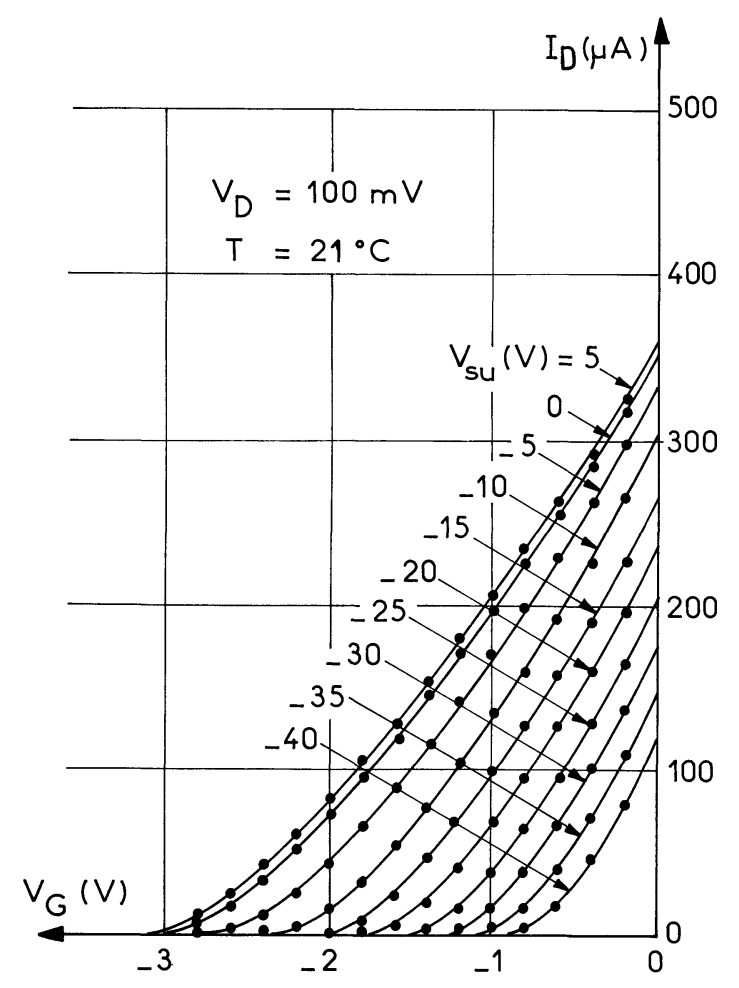

FIG. 3. - Experimental variations of the DC drain current as a function of the gate voltage. Substrate voltage as parameter.
1.2 Current-voltage Characteristics. - The drain current-gate voltage characteristic (Fig. 3), as a function of the substrate bias, translates vertically. At fixed gate bias $V_{\mathrm{G}}$, the drain current $I_{\mathrm{D}}$ (Fig. 4) decreases only when the substrate bias is lower than a negative threshold value noted $V_{\text {SUL }}$.
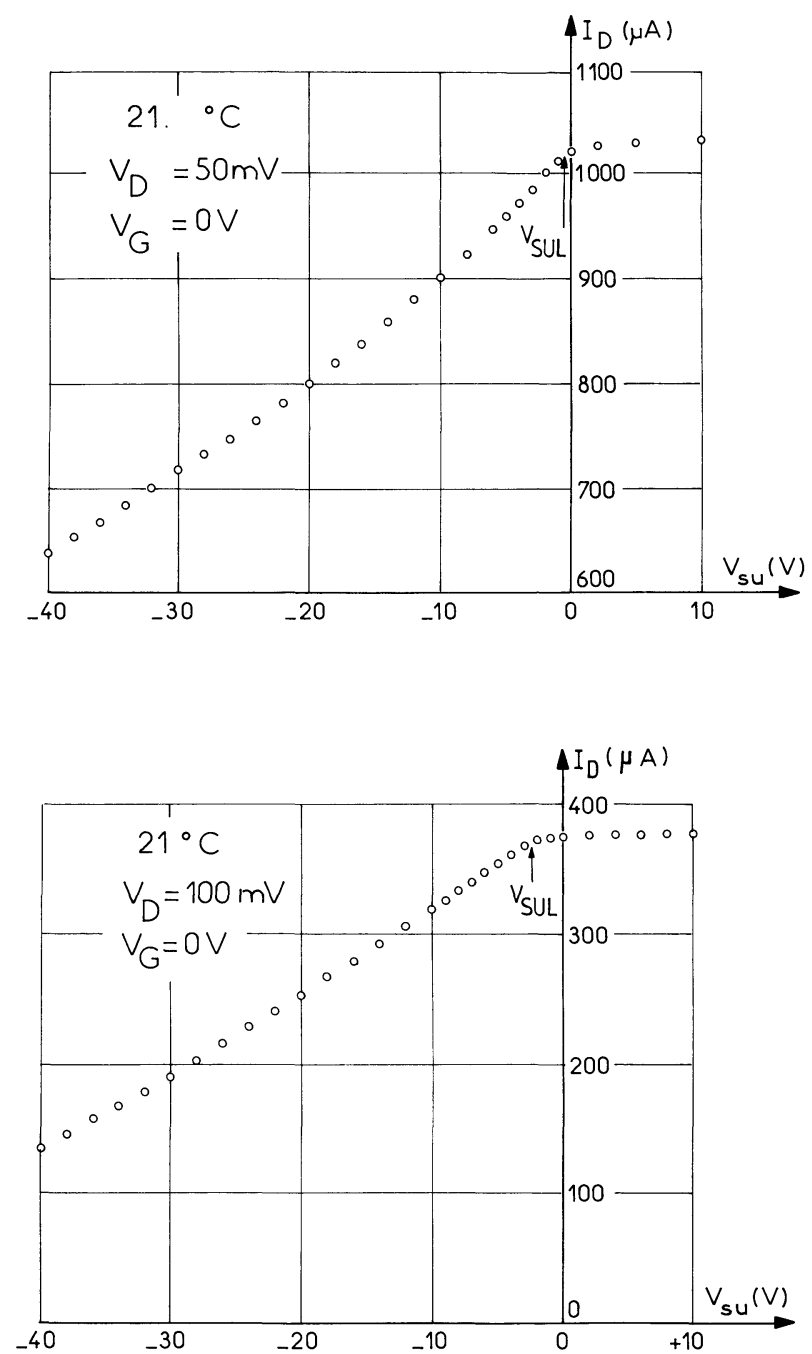

FIG. 4. - Experimental variations of the DC drain current as a function of the substrate voltage. 4.1: Structure T317 No 2 $(L=1 \mu \mathrm{m}) .4 .2$ : Structure T317 No $3(L=50 \mu \mathrm{m})$.

2. Analysis of the results. - From the observed experimental properties and published former studies [3-6], the retained mechanisms are : (i) a depleted space-charge of width $W$ under the gate electrode, (ii) a fixed positive charge $\sigma_{\mathrm{SS}}$ at the semiconductorsemi-insulating interface, similar to that observed in the semiconductor-insulating interface, (iii) at both sides of the interface may exist two space-charges, the negative one in the S.I. is related to a deep centers density $N_{\mathrm{t}}$, whose energy level is several $k T$ above the Fermi level and, the positive one in the semiconductor to the donor density $N_{\mathrm{D}}$. 
The energy level diagrams and the charges distributions are : (i) $V_{\text {su }}>0$ : the structure behaves as a semiconductor-insulating structure, (ii) $V_{\text {su }}=0$ : there is a negative charge build-up in the S.I., (iii) $V_{\text {su }}=V_{\text {SUL }}$, the energy levels in the semiconductor become flat in the interface vicinity, (iv) $V_{\text {su }}<V_{\text {sUL }}$ : there is a double space-charge build-up : a positive one in the semiconductor and a negative one in the S.I. (Fig. 5). Thus the effective channel conduction thickness is reduced to $d-\left(W+x_{\mathrm{d}}\right)$.

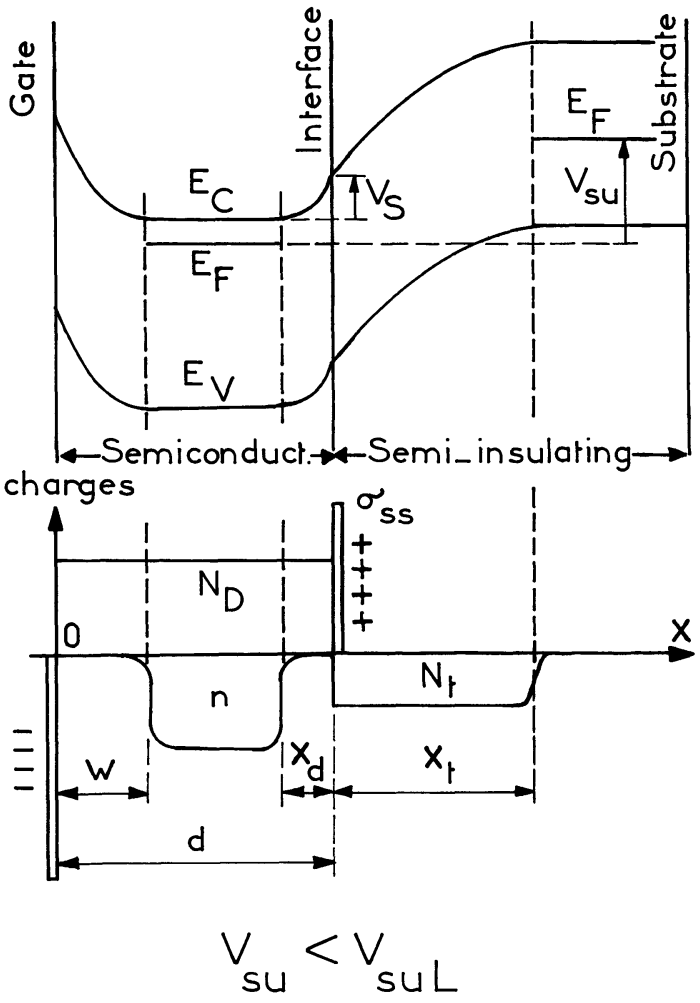

Fig. 5. - Band diagram and charge distribution in a cross-section of the structure.

In this case, the gate threshold voltage $V_{\mathrm{T}}$, defined by the existence of a single point of the semiconductor showing a carrier density $n$ equal $N_{\mathrm{D}}$, is :

$$
\begin{aligned}
& V_{\mathrm{T}}=V_{\mathrm{bi}}-\frac{q N_{\mathrm{D}}}{2 \varepsilon_{0} \varepsilon_{\mathrm{s}}} \times \\
& \times\left[d-\left(\sqrt{\frac{2 \varepsilon_{0} \varepsilon_{\mathrm{s}}}{q N_{\mathrm{D}}} \frac{N_{\mathrm{t}}}{N_{\mathrm{D}}}\left(\varphi_{\mathrm{D}}-V_{\mathrm{SU}}\right)}-\frac{\sigma_{\mathrm{SS}}}{q N_{\mathrm{D}}}\right)\right]^{2}
\end{aligned}
$$

where $V_{\mathrm{bi}}$ and $\varphi_{\mathrm{D}}$ are respectively the gate $-\mathrm{N}$ layer and the $\mathrm{N}$ layer - S.I. built-in potentials.

The drain current at low drain voltage $V_{\mathrm{D}}$, for the ranges $V_{\mathrm{SU}} \leqslant V_{\mathrm{SUL}}$ and $V_{\mathrm{T}} \leqslant V_{\mathrm{G}} \leqslant V_{\mathrm{bi}}$, in the hypothesis of an abrupt space charge-electrically neutral channel boundary, is :

$$
\left.I_{\mathbf{D}}\right|_{V_{\mathbf{D}} \rightarrow 0}=q N_{\mathbf{D}} \mu_{0} \frac{Z d}{L} \times
$$

$$
\begin{aligned}
& \times V_{\mathrm{D}}\left[1-\frac{1}{d}\left(\sqrt{\frac{2 \varepsilon_{0} \varepsilon_{\mathrm{s}}}{q N_{\mathrm{D}}} \frac{N_{\mathrm{t}}}{N_{\mathrm{D}}}\left(\varphi_{\mathrm{D}}-V_{\mathrm{SU}}\right)}-\frac{\sigma_{\mathrm{ss}}}{q N_{\mathrm{D}}}\right)\right] \times \\
& \times\left[1-\sqrt{\frac{V_{\mathrm{bi}}-V_{\mathrm{G}}}{V_{\mathrm{bi}}-V_{\mathrm{T}}}}\right] .
\end{aligned}
$$

In the cases (i, ii, iii), this relation is reduced to $\left(V_{\mathrm{TL}} \leqslant V_{\mathrm{G}} \leqslant V_{\mathrm{bi}}\right):$

$$
\left.I_{\mathrm{DL}}\right|_{\mathrm{V}_{\mathrm{D}} \rightarrow 0}=q N_{\mathrm{D}} \mu_{0} \frac{Z d}{L} V_{\mathrm{D}}\left[1-\sqrt{\frac{V_{\mathrm{bi}}-V_{\mathrm{G}}}{V_{\mathrm{bi}}-V_{\mathrm{T}}}}\right]
$$

with

$$
V_{\mathrm{TL}}=V_{\mathrm{bi}}-\frac{q N_{\mathrm{D}} d^{2}}{2 \varepsilon_{0} \varepsilon_{\mathrm{s}}}
$$

In the four cases, the gate capacitance expression $\left(V_{\mathrm{G}}>V_{\mathrm{TL}}\right.$ or $\left.V_{\mathrm{G}}>V_{\mathrm{T}}\right)$ is :

$$
C=Z L \sqrt{\frac{q \varepsilon_{0} \varepsilon_{\mathrm{s}} N_{\mathrm{D}}}{2\left(V_{\mathrm{bi}}-V_{\mathrm{G}}\right)}} .
$$

3. Application to the determination of the parameters. - (i) The built-in potential $V_{\mathrm{bi}}$ and the donor concentration $N_{\mathrm{D}}$ are deduced from the variations of $1 / C^{2}$ as a function of $V_{\mathrm{G}}$, for $V_{\mathrm{G}}>V_{\mathrm{TL}}$ or $V_{\mathrm{G}}>V_{\mathrm{T}}$.

(ii) The variations of $I_{\mathrm{D}}$ as a function of $\sqrt{V_{\mathrm{bi}}-V_{\mathrm{G}}}$, for a given value $V_{\text {su }}$, is linear with a slope equal to $k \mu_{0} \sqrt{N_{\mathrm{D}}}$ and a $X$ axis intersection equal to $\sqrt{V_{\mathrm{bi}}-V_{\mathrm{T}}}$.

(iii) The variations of the quantity $\sqrt{V_{\mathrm{bi}}-V_{\mathrm{T}}}$ as a function of $\sqrt{\varphi_{\mathrm{D}}-V_{\mathrm{su}}}$ (Fig. 6) present two linear regions and give the quantities

$$
\sqrt{\frac{N_{\mathrm{t}}}{N_{\mathrm{D}}}}, \quad \frac{q N_{\mathrm{D}} d^{2}}{2 \varepsilon_{0} \varepsilon_{\mathrm{s}}}, \quad \frac{\sigma_{\mathrm{ss}}}{\sqrt{2 q N_{\mathrm{D}} \varepsilon_{0} \varepsilon_{\mathrm{s}}}} .
$$

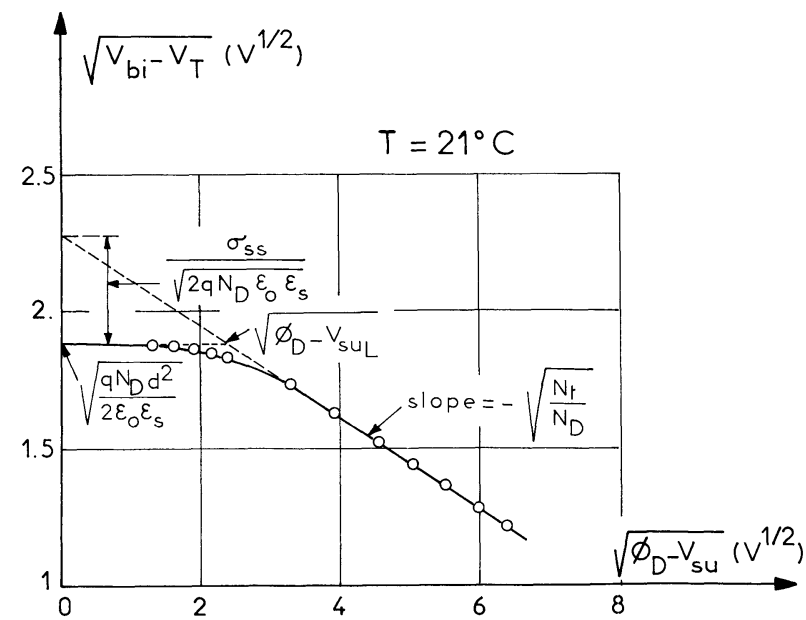

FIG. 6. - Experimental variations of the square-root of $\left(V_{\mathrm{bi}}-V_{\mathrm{T}}\right)$ as a function of the square-root of $\left(\varphi_{\mathrm{D}}-V_{\mathrm{su}}\right)$. Application to the parameters determination. Structure T317 No $2(L=50 \mu \mathrm{m})$.

An example of the parameters values calculated from these quantities (Thomson CSF 310-6 layer) is : $N_{\mathrm{D}}=7.6 \times 10^{16} \mathrm{~cm}^{-3}, V_{\mathrm{bi}}=0.75 \mathrm{~V}, d=0.25 \mu \mathrm{m}$, $\mu_{0}=3900 \mathrm{~cm}^{2} \cdot \mathrm{V}^{-1} \cdot \mathrm{S}^{-1}, N_{\mathrm{t}}=1.9 \times 10^{15} \mathrm{~cm}^{-3}$, $\sigma_{\mathrm{ss}}=6 \times 10^{-4} \mathrm{cb} \cdot \mathrm{cm}^{-2}$. 
4. Effects on the FET electrical characteristics. The time response of the space-charge in the S.I. is responsible for the low-frequency output admittance relaxation phenomenon [7]. One of the most important
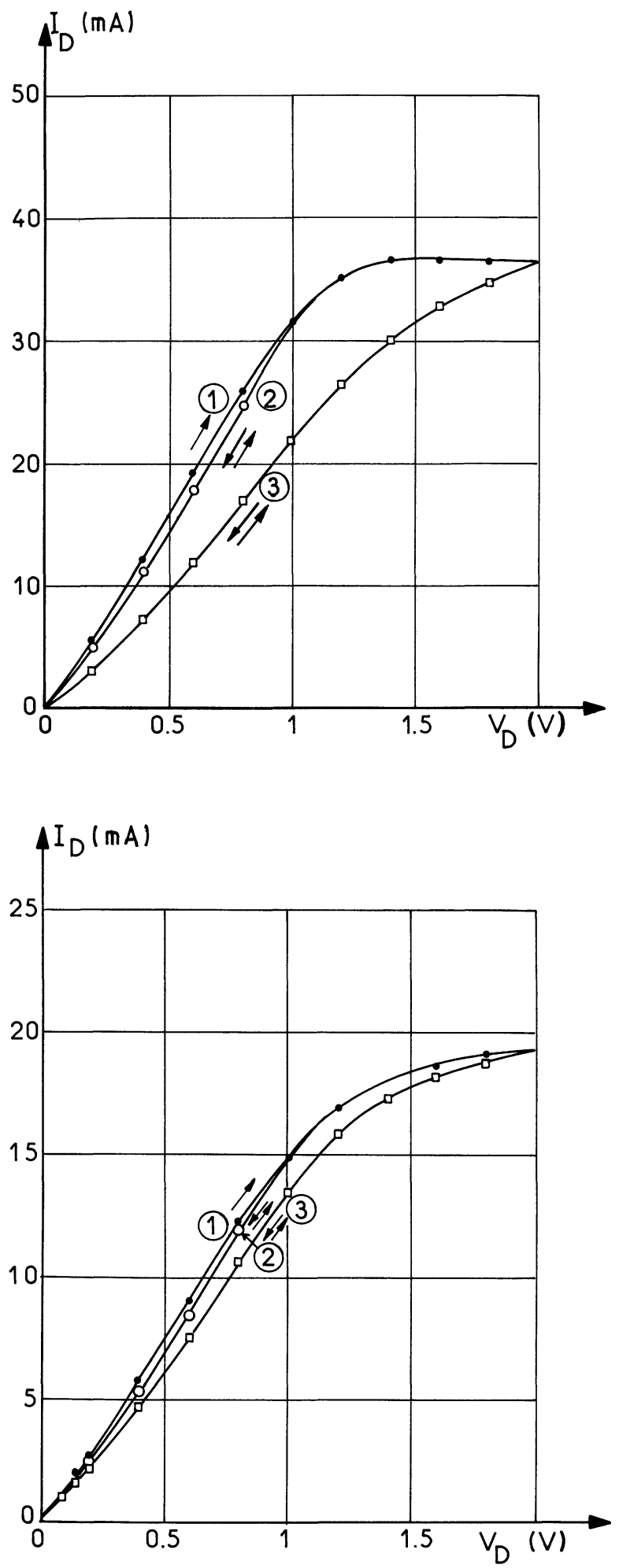

FIG. 7. - Low temperature DC drain current as a function of the drain voltage $T_{\mathrm{a}}=-196^{\circ} \mathrm{C}$. $1:$ initial drain voltage increase $; 2$, $3:$ two following decrease and increase of drain voltage (depending on $V_{D}$ max reached during 1) 7.1 : Unbuffered device. 7.2 : Buffered device. effects of this space-charge is the current-voltage characteristic looping and bumping. An example, at nitrogen liquid temperature, is given (Fig. 7.1). The curve 1 corresponds to the first drain voltage increase and to the build-up of the space-charge in the S.I. and its image space-charge in the semiconductor. The frozen space-charge acts as a fixed charge and controls the following increasing and decreasing drain voltage characteristics (curves 2 and 3). These effects are greatly reduced in FET with a high-resistivity buffer layer [8] (Fig. 7.2). But, due to leakage in the buffer layer, these FETs present high subthreshold current [9] (Fig. 8).

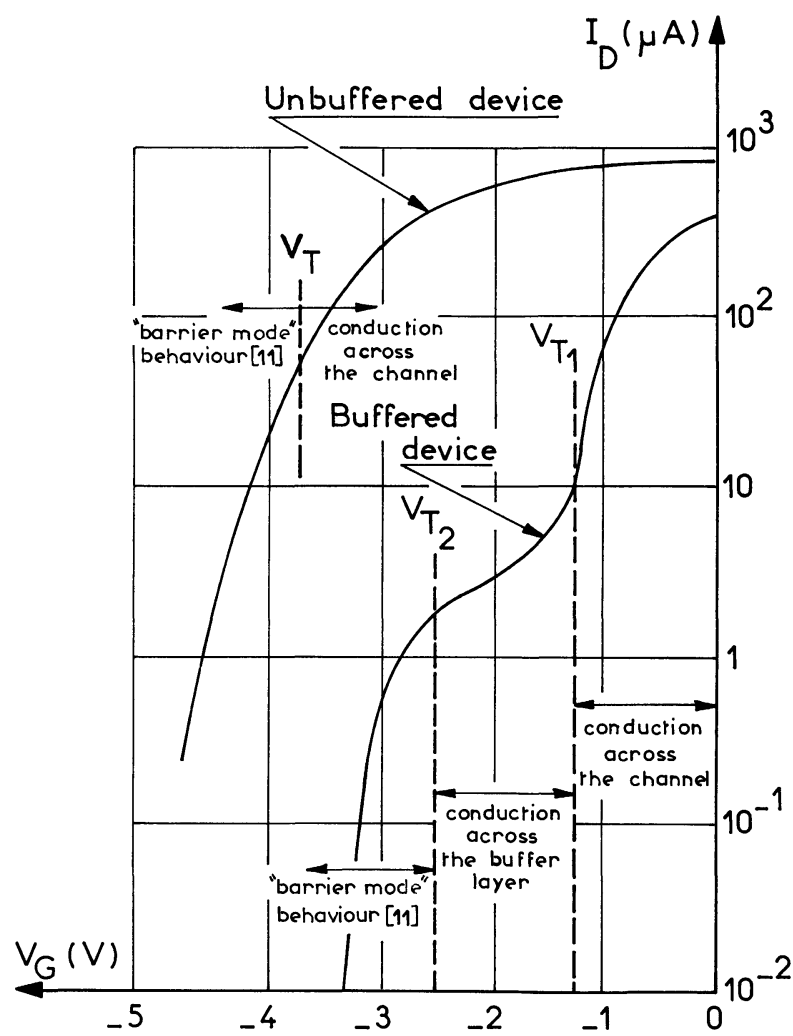

FIG. 8. - Classical and subthreshold drain currents in a buffered and an unbuffered devices showing the current leakage effect through the buffer layer.

Thus, though the multi-layer technology improves the RF performances, it must be forbidden in highspeed switching logic circuits which need good blocking characteristics.

5. Conclusion. - A way to determine the parameters of $\mathrm{N}^{+}$epilayer on semi-insulating substrate is proposed. It consists in a substrate bias which acts on the electrostatic configuration of the semiconductorsemi-insulating interface. The physical origin of the deep centers $N_{\mathrm{t}}$ and the interface charge $\sigma_{\mathrm{Ss}}$ are unknown though these deep centers are related to chromium [10]. The current-voltage characteristic looping and the low-frequency relaxation phenomenon are finally related to the semi-insulating space-charge. 


\section{References}

[1] Barrera, J., 5th Biennal Cornell Electrical Conf. II.3 (1975) 135.

[2] Duchemin, J. P., Bonnet, M., Huyghe, D., Rev. Techn. Thomson CSF 9 (1977) no 4, 685.

[3] HoOper, W. W., CaIRns, B. R., Technical Report AFAL-TR69-30 (1969) 28.

[4] Lehovec, K., ZuleEg, R., Gallium arsenide and related compounds, Inst. Phys. Conf. Ser. no 24 (1975) 292.

[5] Tanimoto, M., Suzuki, K., IтoH, T., IKoma, T., YanaI, H., Kaufmann, L. M. F., Nievendick, W., Heime, K., 6th ESSDERC, München, B 4 (1976).

[6] Yokohama, N., Shibatomi, A., Ohkawa, S., Fukuta, M.,
IsHIKAWA, Gallium arsenide and related compounds, Inst. Phys. Conf. Ser. no 33b (1977) 201.

[7] Rossel, P., Tranduc, H., Graffeuil, J., Azizi, C., Revue Phys. Appl. 12 (1977) 1679.

[8] Nozaki, T., Ogawa, M., TeraO, H., Watanabe, H., Gallium arsenide and related compounds, Inst. Phys. Conf. Ser. $n^{\circ} 24$ (1975) 46.

[9] Azizi, C., Rossel, P., Tranduc, H., Graffeuil, J., $C . R$. Hebd. Séan. Acad. Sci. Paris (1977) B 285145.

[10] Houng, Y., Stanford University, Ph.D. Thesis (1977) p. 44. [11] BREWER, R. J., Solid State Electron. 18 (1975) 1013. 